\title{
PENGEMBANGKAN POTENSI WISATA DAN PENDIDIKAN ISLAMI PADA ERA COVID-19
}

\author{
Ari Ambarwati*, Nurlatifah Islami, Indah Dwi Aprilia, Badii' Fauziah Masruroh \\ Fakultas Keguruan dan Ilmu Pendidikan, Universitas Islam Malang \\ *korespondensi email: ariati@unisma.ac.id
}

\begin{abstract}
ABSTRAK
Pada era Covid-19 seperti saat ini banyak hal yang mengalami perubahan. Perubahan pada sektor ekonomi diyakini paling berdampak oleh seluruh masyarakat Indonesia. Hal ini juga dialami oleh para pengrajin keramik di Kampung Wisata Keramik Dinoyo, Malang. Semenjak pandemi Covid-19, para pengunjung di kampung wisata keramik menurun drastis lebih dari 50\%. Maka dari itu, diperlukan adanya inovasi untuk membantu memajukan kembali potensi wisata di wilayah tersebut yaitu dengan pembuatan spot foto, denah penunjuk arah, dan pemberian ilmu agama di TPQ Al-Falah. Tujuan dari kegiatan ini adalah untuk meningkatkan potensi wisata kampung keramik dan juga untuk menerapkan ilmu yang telah kami peroleh di tingkat universitas. Dalam metode pelaksanaan program kerja ini, kami membagi tim siapa saja yang bertugas dalam pembuatan spot foto dan siapa saja yang bertugas dalam mengajar ngaji. Hasil dari program kerja kami berupa spot foto yang menarik, denah penunjuk arah, dan juga ilmu yang bermanfaat bagi para santriwan dan santriwati di TPQ Al-Falah. Diharapkan dengan adanya inovasi dari KSM-T 52 Universitas Islam Malang dapat menyelesaikan permasalahan yang dihadapi oleh warga Kampung Wisata Keramik Dinoyo, Malang.
\end{abstract}

Kata Kunci: era covid-19; inovasi; potensi wisata

\section{PENDAHULUAN}

Setiap daerah memiliki potensi wisata berbeda-beda, bahkan ada yang memiliki potensi besar namun belum di sentuh agar menjadi daya tarik wisata yang mengagumkan. Potensi wisata adalah segala sesuatu yang dimiliki oleh daerah tujuan wisata, dan merupakan daya tarik agar orang-orang mau datang berkunjung ke tempat tersebut (Rumijati et al., 2021; Silitonga \& Anom, 2016). Sedangkan pengertian potensi wisata menurut Gunardi (2010) potensi wisata adalah segala sesuatu yang dimiliki oleh suatu daerah untuk daya tarik wisata dan berguna untuk mengembangkan industri pariwisata di daerah tersebut.

Potensi wisata alam adalah keadaan, jenis flora dan fauna suatu daerah, bentang alam seperti pantai, hutan, pegunungan dan lain-lain (keadaan fisik suatu daerah (Rusita et al., 2016; Walimbo et al., 2017). Potensi wisata kebudayaan adalah semua hasil cipta, rasa dan karsa manusia baik berupa adat istiadat, kerajinan tangan, kesenia, peninggalan sejarah berupa bangunan (Contoh monumen) (Kenzie, 2016). Potensi wisata manusia juga sebagai daya tarik wisata berupa, pementasan tarian, pementasan atau pertunjukan seni budaya suatu daerah (Cahyanto et al., 2020). 
Dari pengertian diatas dapat dipahami bahwa potensi wisata yang ada di Kampung Wisata Keramik Dinoyo, Malang adalah potensi wisata kebudayaan, yaitu dengan mengembangkan kerajinan keramik yang tersedia dalam berbagai model dan bentuk yang dikerjakan oleh hampir seluruh pengrajin di wilayah tersebut. Perlu diketahui bahwa Kampung Wisata Keramik Dinoyo, Malang sudah banyak dikunjungi oleh wisatawan domestik dan mancanegara. Namun, sejak pandemi covid-19 para pengunjung di Kampung Wisata Keramik Dinoyo, Malang mengalami penurunan yang drastis. Hal ini mengakibatkan turunnya omset penghasilan yang diterima oleh setiap pengrajin di Kampung Wisata Keramik Dinoyo, Malang. Apabila dalam potensi wisata di Kampung Wisata Keramik Dinoyo Malang mengalami penurunan, berbeda dengan pendidikan islami yang ada di wilayah tersebut.

Dengan beralihnya sistem pendidikan formal menjadi "online" yang mana mengharuskan anak-anak untuk belajar di rumah tanpa harus bertatap muka dengan guru dan teman-temanya, hal ini justru berbanding terbalik dengan apa yang ada di Kampung Wisata Keramik Dinoyo, Malang. Mereka justru sangat antusias dalam menuntut ilmu AlQur'an dengan bimbingan para ustadz tanpa harus mengaji secara "online". Oleh karena itu, melihat dari situasi dan kondisi yang ada, kami mahasiswa/i KSM-T kelompok 52 berinisiatif untuk mengembangkan potensi wisata di Kampung Wisata Keramik Dinoyo Malang agar daerah tersebut tidak seperti "kampung mati" karena sepi pengunjung. Kami memiliki program yaitu dengan pembuatan spot foto dan denah penunjuk arah agar memudahkan para pengunjung untuk mengetahui tempat-tempat apa saja yang ada di Kampung Wisata Keramik tersebut. Disamping itu, kami juga membantu memberikan pendidikan Islami di wilayah tersebut tepatnya di TPQ Al-Falah juga untuk membantu para ustadz dalam memberikan ilmu berbasis islami yang bermanfaat bagi para santriwan dan santriwati.

\section{METODE}

Kegiatan ini berlangsung mulai 8 Februari sampai dengan 2 Maret 2021. Dimana dengan anggota kelompok kami yang berjumlah 10 orang, kami membagi tugas untuk melaksanakan program kerja tersebut. Di pagi hari, ada yang mengerjakan spot foto di area pabrik keramik, dan di sore hari ada yang mengajar ngaji di TPQ Al-Falah. Kegiatan ini diawali dengan diskusi bersama Bapak Samsul Arifin selaku ketua paguyuban Kampung Wisata Keramik Dinoyo Malang dan juga para ustadz di TPQ Al-Falah.

1. Survei Lokasi

Survei lokasi ini bertujuan untuk menyesuaikan dengan tema kegiatan yang telah di pilih sebelumnya serta dapat di jadikan acuan apakah ada masalah lain yang terjadi selama pandemi Covid-19 yang dapat ditemukan solusinya.

2. Diskusi bersama Pihak Paguyuban Kampung Wisata Keramik Dinoyo, Malang

Kegiatan ini diwakili oleh beberapa anggota KSM-T kelompok 52 dengan Pak Samsul Arifin untuk membicarakan tentang program kerja apa yang dapat kami laksanakan di tempat tersebut sekaligus meminta izin kepada beliau, dengan harapan mahasiswa/i KSM-T kelompok 52 dapat diterima dengan baik oleh warga sekitar dan juga untuk membantu mengatasi permasalahan yang ada.

3. Diskusi bersama Para Ustadz di TPQ Al-falah

Setelah berdiskusi dengan pihak paguyuban, dilanjutkan dengan berdiskusi dengan pihak TPQ Al-Falah untuk membicarakan mengenai bagaimana metode pengajaran yang dilakukan di TPQ tersebut dan juga untuk membicarakan inovasi dan kreativitas apa saja yang perlu kami lakukan agar santriwan dan santriwati tidak merasa bosan dan juga sebagai referensi untuk para ustadz dalam mentransfer ilmu Al-Qur'an di TPQ Al-Falah. 
4. Pelaksanaan Kegiatan

Mahasiswa/i KSM-T kelompok 52 memulai kegiatan untuk pembuatan spot soto dimulai dengan pembersihan lahan, pengecatan dinding/background, pembelian atribut, dan diakhiri dengan pemasangan atribut spot foto. Sedangkan untuk mengajar mengaji di TPQ Al-Falah, mahasiswa/i KSM-T kelompok 52 memulai kegiatan dengan sholat ashar berjamaah dengan warga setempat, pembacaan do'a sebelum mengaji, dilanjutkan dengan para santriwan dan santriwati mengaji dimana mereka mengahampiri kami sebagai tenaga pendidik, kemudian pemberian materi yang diwakilkan oleh salah satu anggota KSM-T kelompok 52, dan diakhiri dengan do'a penutup sebelum pulang. Tak lupa kami selalu menerapkan protokol kesehatan seperti mencuci tangan sebelum memulai dan setelah mengakhiri kegiatan, memakai masker, menggunakan hand sanitazer, dan juga menjaga jarak.

5. Analisis Kegiatan

Analisis kegiatan perlu di lakukan guna memperbaiaki kekurangan selama kegiatan berlangsung. Yang mana akan berguna pada tahap selanjutnya yaitu tahap evaluasi.

6. Evaluasi Hasil Kegiatan

Setelah melakukan tahap analisis, kemudian di evaluasi. Tujuannya adalah untuk mengetahui apa saja kendala atau masalah yang di temukan selama pelaksanaan kegiatan, sehingga dapat menemukan solusi terkait permasalahan yang ada.

\section{HASIL DAN PEMBAHASAN}

Dengan kondisi Covid-19 yang masih berlangsung menjadi tantangan tersendiri bagi kami untuk melaksanakan KSM di Kampung Wisata Keramik Dinoyo, Malang. Namun tentangan tersebut justru menjadikan motivasi tersendiri bagi kami, apakah kami mampu melaksanakan program kerja ini dengan baik atau tidak. Apabila melihat kondisi sebelumnya yang mana pengunjung Kampung Wisata Keramik Dinoyo, Malang berjumlah banyak mulai dari kalangan pelajar, mahasiswa, masyarakat umum, serta mancanegara, saat ini jumlah pengunjung tersebut menurun drastis melebihi $50 \%$.

Maka dari itu, kami membuat spot foto di area pabrik kampung keramik dengan harapan meskipun pengunjung mengalami penurunan, mereka masih bisa datang dan berfoto di area tersebut dan dapat mempublikasikan di media sosial agar Kampung Wisata Keramik Dinoyo, Malang semakin dikenal oleh masyarakat luas dan para pegrajin tidak terlalu merugi karena mengalami penurunan omset penghasilan. Dalam hal pembuatan denah penujuk arah, selain ditujukan kepada para pengunjung juga ditujukan kepada masyarakat yang melintas di wilayah tersebut agar dapat mengetahui tempat-tempat apa saja yang terdapat di Kampung Wisata Keramik Dinoyo, Malang. Melalui penjabaran diatas, Kampung Wisata Keramik Dinoyo, Malang memang tempat yang tepat untuk melaksanakan program kerja kami. Dalam hal pembuatan spot foto, area yang ada memang sudah sesuai dengan apa yang diharapkan. Selain itu, karena pembuatan spot foto ditempatkan di halaman depan pabrik keramik yang luas dan dekat dengan tempat parkir pengunjung, memudahkan para pengunjung untuk melihat spot foto yang telah dibuat dan tertarik untuk mengambil gambar di area tersebut. Sedangkan untuk pemasangan denah penunjuk arah diletakkan di depan pabrik keramik dimana bertujuan untuk memudahkan masyarakat yang melintasi wilayah tersebut agar mengetahui titik lokasi Kampung Wisata Keramik Dinoyo, Malang.

Sementara itu di tempat yang berbeda, yakni di TPQ Al-Falah kami tidak menemukan tantangan yang terlalu sulit dikarenakan proses mengaji yang berjalan seperti biasanya. Tantangan yang kami temukan mungkin karena mayoritas anggota KSM-T kelompok 52 belum pernah memiliki pengalaman mengajar ngaji, sehingga menyebabkan sulitnya 
menkondisikan, mengatur, serta pemberian materi apa yang sesuai dengan usia mereka. Oleh karena tidak adanya perubahan yang terlalu signifikan, alhasil kami hanya perlu memberikan inovasi tentang pemberian materi di TPQ Al-Falah. Kami memiliki inovasi dalam pemberian materi setelah santriwan/wati selesai mengaji, berupa materi tentang Makhroijul Huruf, Asmaul Husna, Praktek Wudhu, dan Kalimat Thoyyibah. Kegiatan mengajar mengaji di TPQ Al-Falah berlangsung setiap hari senin-kamis pukul 15.30-16.30 yang dihadiri 5-7 anggota kelompok KSM-T 52. Setiap anggota kelompok KSM-T 52 memegang 2-3 santriwan dan santriwati untuk mengaji sekaligus untuk memeriksa tulisan ayat Al-Qur'an yang mereka kerjakan. Para santriwan/wati berjumlah kurang lebih 30 anak yang terdiri dari tingkatan PAUD sampai dengan SMP dan para ustadz yang berjumlah 4 orang. Untuk metode yang digunakan di TPQ Al-Falah menggunakan Iqra' dan Al-Qur'an. Adapun kegiatan yang kami lakukan di Kampung Wisata Keramik Dinoyo Malang, antara lain:

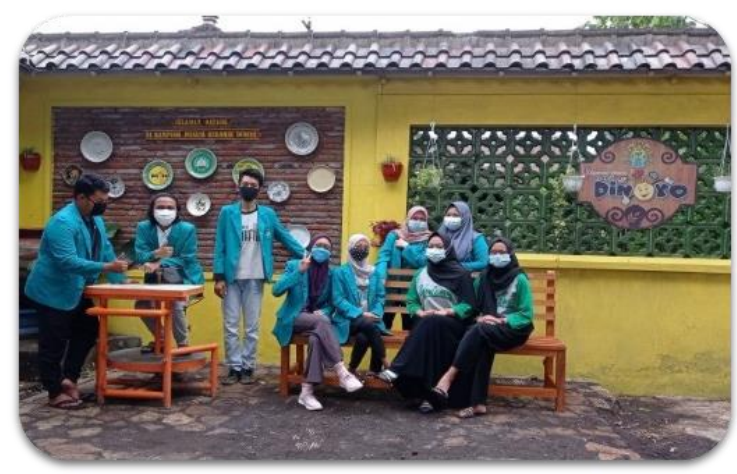

Gambar 1. area spot foto yang telah selesai dikerjakan oleh anggota KSM-T kelompok 52

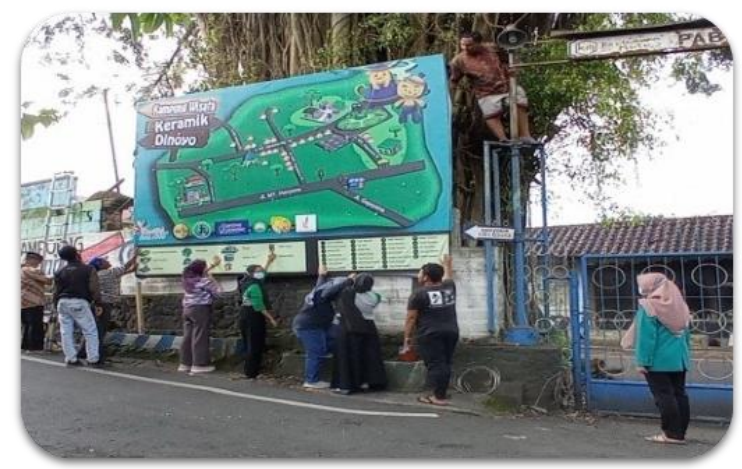

Gambar 2. Pemasangan denah penunjuk arah yang telah dibuat



Gambar 3. proses pengecatan area spot foto 


\section{KESIMPULAN}

Pengembangan potensi wisata dan pendidikan islami di Kampung Wisata Keramik Dinoyo, Malang yang diselenggarakan oleh mahasiswa/i KSM-T kelompok 52 dilaksanakan di pabrik keramik Dinoyo Malang dan juga di TPQ Al-Falah. Program kerja ini bertujuan untuk menambah ilmu dan pengalaman bagi kami mahasiswa/i KSM-T kelompok 52 diluar universitas, dan juga untuk membantu mengembangkan potensi wisata Kampung Keramik yang mengalami penurunan akibat adanya pandemi Covid-19. Selain itu, juga untuk menerapkan ilmu yang telah kami peroleh di universitas kepada santriwan dan santriwati di wilayah tersebut berupa pendidikan islami era Covid-19.

Pelaksanaan kegiatan ini berupa pembuatan spot foto di area pabrik keramik, pembuatan denah penunjuk arah, dan juga pendidikan islami di TPQ Al-Falah. Diharapkan dengan adanya program kerja yang kami laksanakan dapat bermanfaat bagi seluruh warga Kampung Wisata Keramik Dinoyo Malang. Pelaksanaan program kerja oleh KSM-T kelompok 52 ini disambut antusias oleh para santriwan/wati yang mengaji di TPQ Al-Falah dan juga oleh Bapak Samsul Arifin selaku ketua paguyuban di Kampung Wisata Keramik Dinoyo, Malang.

\section{UCAPAN TERIMA KASIH}

Terimakasih disampaikan kepada Ketua Pokdarwis Kampung Wisata Keramik Dinoyo beserta jajarannya. Warga kampung wisata keramik Dinoyo, serta LPPM (Lembaga Penelitian dan Pengabdian Masyarakat) Universitas Islam Malang.

\section{DAFTAR RUJUKAN}

Cahyanto, B., Khasanah, S. A., Khausumah, N., Rukhoyah, S. N., Miftahunnikmah, M., Diky Kurniyanto, M. I., Brata, R. D., Kapsir, K., Taranggana Aji, D. S., Harianto, H., \& Sabdogati, S. D. (2020). Pemberdayaan Masyarakat Desa Dalam Pembuatan Taman Sebagai Media Pengembangan Desa Wisata. Jurnal Pembelajaran Pemberdayaan Masyarakat (JP2M), 1(3), 193. https://doi.org/10.33474/jp2m.v1i3.6600

Gunardi, G. (2010). Identifikasi Potensi Kawasan Wisata Kali Pasir, Kota Tangerang. Jurnal $\begin{array}{lll}\text { Planesa (Planologi), } & \text { 28-35), }\end{array}$ https://ejurnal.esaunggul.ac.id/index.php/planesa/article/view/510

Kenzie, A. (2016). Pengertian dan Macam-macam Potensi Wisata. Ady Kenzie Blog. https://adykenzie.blogspot.com/2016/08/pengertian-dan-macam-macampotensi.html

Rumijati, A., Asfiah, N., \& Fiandari, Y. R. (2021). Peningkatan potensi desa wisata melalui pengembangan kemasan oleh-oleh. Jurnal Inovasi Hasil Pengabdian Masyarakat (JIPEMAS), 4(1), 90-99. https://doi.org/10.33474/jipemas.v4i1.9049

Rusita, Walimbo, R., Sari, Y., \& Yanti, M. (2016). Air Terjun Wiyono Di Taman Hutan Raya Wan Abdul Rahman, Provinsi Lampung. Jurnal Info Teknik, 17(2), 165-186. https://doi.org/10.20527/infotek.v17i2.2494

Silitonga, S. S. M., \& Anom, I. P. (2016). Kota Tua Barus Sebagai Daerah Tujuan Wisata Sejarah Di Kabupaten Tapanuli Tengah. Jurnal Destinasi Pariwisata, 4(2), 7-13. https://doi.org/10.24843/despar.2016.v04.i02.p02

Walimbo, R., Wulandari, C., \& Rusita. (2017). Studi Daya Dukung Ekowisata Air Terjun Wiyono Di Taman Hutan Raya Wan Abdul Rachman Provinsi Lampung (the Study of Carrying Capacity of Wiyono Waterfall Ecotourism in Wan Abdul Rachman Great Forest Park Lampung Province). Jurnal Sylva Lestari, 5(1), 47-60. https://doi.org/10.23960/jsl1547-60 